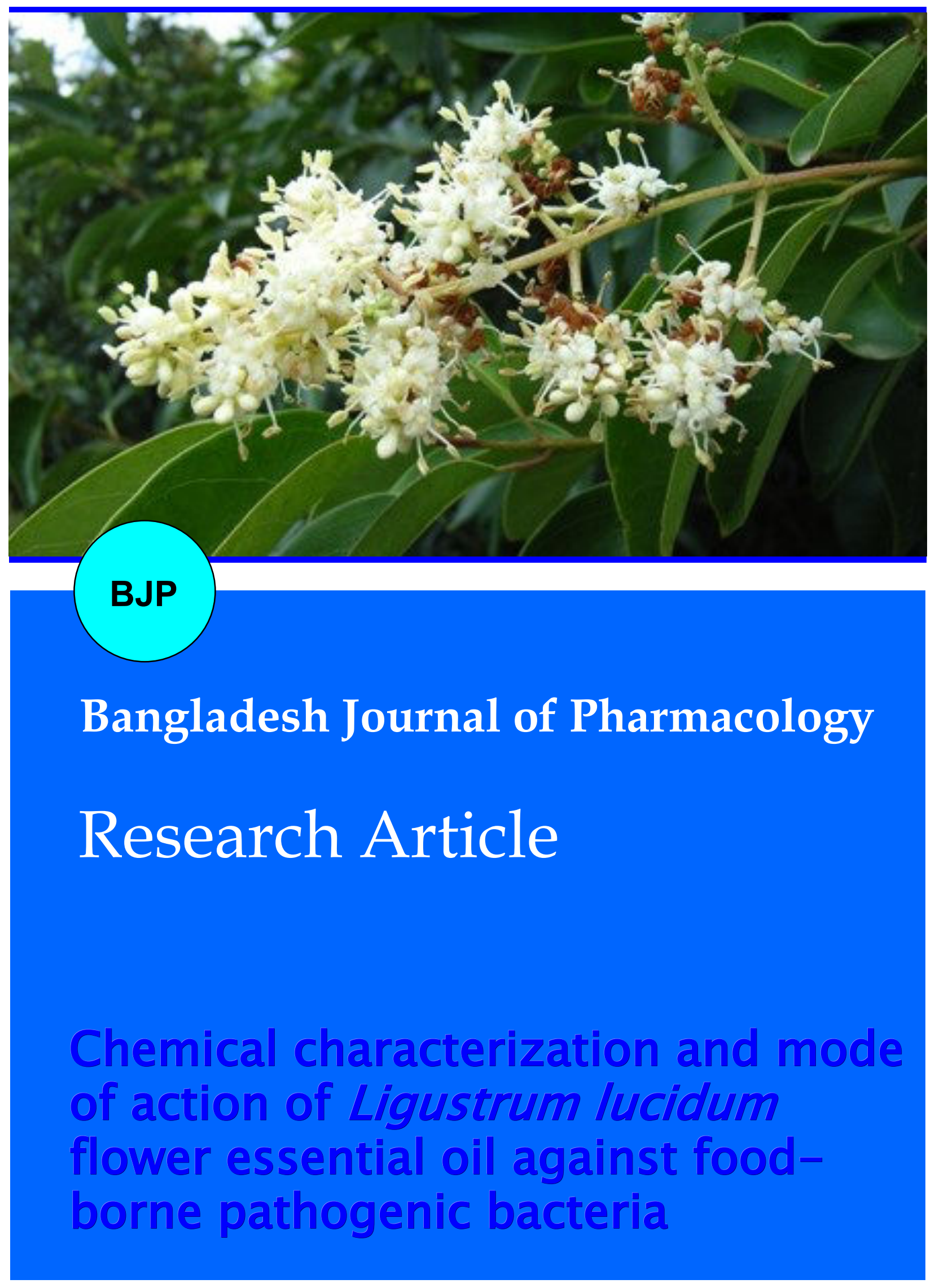




\title{
Chemical characterization and mode of action of Ligustrum lucidum flower essential oil against food-borne pathogenic bacteria
}

\author{
Vivek K. Bajpai ${ }^{1}$, Siddhartha Singh ${ }^{2}$ and Archana Mehta ${ }^{2}$ \\ ${ }^{1}$ Department of Applied Microbiology and Biotechnology, School of Biotechnology, Yeungnam University, \\ Gyeongsan, Gyeongbuk 712 749, Republic of Korea; ' Department of Botany, Dr. Hari Singh Gour University, \\ Sagar 470 003, Madhya Pradesh, India.
}

\begin{tabular}{|c|c|}
\hline \multicolumn{2}{|l|}{ Article Info } \\
\hline Received: & 26 October 2015 \\
\hline Accepted: & 28 January 2016 \\
\hline Available Online: & 30 January 2016 \\
\hline \multicolumn{2}{|c|}{ DOI: 10.3329/bjp.v11i1.25487 } \\
\hline \multicolumn{2}{|c|}{$\begin{array}{l}\text { Cite this article: } \\
\text { Bajpai VK, Singh S, Mehta A. Chemi- } \\
\text { cal characterization and mode of ac- } \\
\text { tion of Ligustrum lucidum flower es- } \\
\text { sential oil against food-borne patho- } \\
\text { genic bacteria. Bangladesh } \\
\text { Pharmacol. 2016; 11: } 269-80 \text {. }\end{array}$} \\
\hline
\end{tabular}

\begin{abstract}
Current research analyzes the chemical composition of Ligustrum lucidum flower essential oil obtained by the hydrodistillation, and examines its antimicrobial mode of action against food-borne pathogenic bacteria. Gas chromatography-mass spectrometry analysis of the oil resulted in the determination of 44 different compounds, representing $85.2 \%$ of the total oil. The oil (1 mg/disc) showed significant antibacterial effect as diameters of inhibition zones (14.6 $\pm 0.2-19.7 \pm 0.3 \mathrm{~mm})$, as well as minimum inhibitory and minimum bactericidal concentrations values (250-1000 and 250-2000 $\mu \mathrm{g}$ / $\mathrm{mL})$, respectively. Based on the susceptibility, L. lucidum flower oil revealed its mode of action on membrane integrity as confirmed by increased release of extra-cellular ATP (2.5 and $2.2 \mathrm{pg} / \mathrm{mL}$ ), leakage of potassium ions (950 and $900 \mathrm{mM} / \mathrm{L}$ ), loss of 260-nm absorbing materials (4.2 and 3.9 optical density), and increase in relative electrical conductivity (10.6 and 9.8\%) against Staphylococcus aureus KCTC-1621 (Gram-positive) and Salmonella enterica ATCC-4731 (Gram-negative), respectively.
\end{abstract}

\section{Introduction}

There has recently been considerable concern with the increasing incidence of food-borne diseases, which have become relevant public health issues (Oussalah et al., 2007; da Silveira et al., 2012). In spite of the advances in the sanitation techniques and inspection services, the contamination of foods with undesirable microorganisms is a potential risk during food processing, reprocessing, storage and distribution both in developing and developed countries (Runyora et al., 2010).

Although synthetic preservatives have shown remarkable effectiveness as antimicrobials, they might be detrimental to human health (Aiyelaagbe et al., 2007). Hence, application of essential oils as safe and effective alternatives to synthetic preservatives in controlling pathogenic bacteria may able to reduce the risk of foodborne outbreaks and may assure consumers with safe and microbially-contaminated free food products (Yoon et al., 2011).

Ligustrum lucidum is a species of privet (Ligustrum genus), a flowering plant in the olive family, Oleaceae, native to the southern half of China and naturalized in several other countries including Spain, Italy, Japan, and Korea. The seeds of L. lucidumare known to use in traditional Chinese medicine (Chen, 2012). In studies of laboratory animals, the herbal extracts derived from L. lucidum have been shown to have anti-inflammatory, antidiabetic, anti-hyperlipidemic, and hepatoprotective properties (Chen, 2012). However, not much research has been focused on the floral parts of L. lucidum.

Present study characterizes the chemical composition of essential oil isolated from the floral parts of L. lucidum and evaluates its antimicrobial mode of action against food-borne pathogenic bacteria. 


\section{Materials and Methods \\ Collection of sample and oil preparation}

The flowers of L. lucidum were collected in March 2015 from the local area of Gyeongsan City, Gyeongbuk, Republic of Korea, and identified by the taxonomist and the data-base present at the Department of Applied Microbiology and Biotechnology, Yeungnam University, Korea. A voucher specimen has been deposited in the herbarium of Laboratory of Microbiology, under the number (DPT/Herb/2015-15). The flowers were dried, powdered and passed through 40-mesh sieve and stored in an airtight container for further use. The powdered flower material (100 g) was subjected to hydrodistillation for 3 hours, using a Clevenger apparatus. The oil was dried over anhydrous $\mathrm{Na}_{2} \mathrm{SO}_{4}$ and preserved in an airtight vial at low temperature $\left(4^{\circ} \mathrm{C}\right)$ for further analysis.

\section{Gas chromatography-mass spectrometry (GC-MS)} analysis

A detailed chemical composition analysis of flower essential oil of L. lucidum was performed using a GC/ MS (Jeol JMS 700 GC-MS spectrometer) equipped with an Agilent 6890N GC DB-5 MS fused silica capillary column $(30 \mathrm{~m} \times 0.25 \mathrm{~m}$ i.d., film thickness $0.25 \mu \mathrm{m})$. For GC-MS detection, an electron ionization system with ionization energy of $70 \mathrm{eV}$ was used. Helium gas was used as the carrier gas at a constant flow rate of $1 \mathrm{~mL} /$ min. Injector and MS transfer line temperature were set at 280 and $250^{\circ} \mathrm{C}$, respectively. The initial oven temperature of $50^{\circ} \mathrm{C}$ was maintained for $2 \mathrm{~min}$, and then increased to $250^{\circ} \mathrm{C}$ at a rate of $10^{\circ} \mathrm{C} / \mathrm{min}$ followed by holding at $250^{\circ} \mathrm{C}$ for $10 \mathrm{~min}$. Diluted samples (1/100, v/ $\mathrm{v}$, in methanol) of $1.0 \mu \mathrm{L}$ were injected manually in the split-less mode. The relative percentage of the oil constituents was expressed as percentages by peak area normalization. Identification of essential oil components was based on GC retention time on a DB-5 capillary column relative to computer matching of mass spectra using Wiley and NIST libraries for the GC-MS system.

\section{Microorganisms}

The test food-borne pathogens included Staphylococcus aureus KCTC-1621, Bacillus subtilis KCTC-3569, Listeria monocytogenes KCTC-3569, Salmonella enterica ATCC4731 and Escherichia coli O157:H7. All the bacterial strains were grown in the nutrient broth $(\mathrm{NB})$ at $37^{\circ} \mathrm{C}$. The bacterial strains were maintained on nutrient agar slants at $4^{\circ} \mathrm{C}$.

\section{Determination of antibacterial activity by disc diffu- sion assay}

Standard agar diffusion method was used for the determination of antibacterial efficacy of flower essential oil of L. lucidum (Bajpai et al., 2013). Petri-plates were prepared by pouring $20 \mathrm{~mL}$ of nutrient agar medium and allowed to solidify. Plates were dried and $1 \mathrm{~mL}$ of standardized inoculum containing $10^{7} \mathrm{CFU} /$ $\mathrm{mL}$ of bacterial suspension was poured and uniformly spread, and the inoculum was allowed to dry for $5 \mathrm{~min}$. A Whatman No. 1 sterile filter paper disc $(6 \mathrm{~mm}$ diameter) was impregnated with $1 \mathrm{mg} /$ disc of flower oil of L. lucidum. The oil was dissolved in 5\% dimethyl sulfoxide (DMSO). Negative controls were prepared using DMSO. Standard reference tetracycline $(25 \mu \mathrm{g} /$ disc) was used as a positive control against the tested bacteria. The plates were incubated at $37^{\circ} \mathrm{C}$ for 24 hours. Antibacterial activity was evaluated by measuring the diameters of inhibition zones against the tested bacteria. Each assay in this experiment was performed in triplicate.

\section{Determination of minimum inhibitory and minimum bactericidal concentrations}

The minimum inhibitory concentration (MIC) of flower essential oil of L. lucidum was tested by two-fold serial dilution method (Bajpai et al., 2013). The oil was first dissolved in DMSO and incorporated into nutrient broth (NB) medium for bacterial pathogens to obtain a concentration of $2000 \mu \mathrm{g} / \mathrm{mL}$, and serially diluted to achieve 1,000, 500, 250, 125, 62.5, 31.25, 15.62 and 7.81 $\mu \mathrm{g} / \mathrm{mL}$, respectively. A $10 \mu \mathrm{L}$ standardized suspension of each tested organism (approximately $10^{7} \mathrm{CFU} / \mathrm{mL}$ ) was transferred to each tube. The control tubes containing only bacterial suspensions were incubated at $37^{\circ} \mathrm{C}$ for 24 hours. The lowest concentration of oil, which did not show any visible growth of test organisms after macroscopic evaluation, was determined as MIC. Further, the concentrations showing complete inhibition of visual growth of bacterial pathogens were identified, and $50 \mu \mathrm{L}$ of each culture broth was transferred on to the agar plates and incubated for specified time and temperature as mentioned above. The complete absence of growth of bacterial colonies on the agar surface was the lowest concentration of sample and was defined as the minimum bactericidal concentration (MBC). Each assay in this experiment was replicated three times. A visual demonstration of this assay has been given in attached video content.

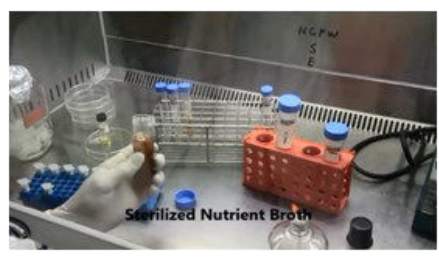

\section{Effect on viable counts of bacterial pathogens}

Based on the susceptibility of bacterial pathogens used in this study, two strains S. aureus KCTC-1621 (Grampositive) and S. enterica ATCC-4731 (Gram-negative) were selected for further studies. Active cultures for 
viable count assay were prepared in NB broth medium, grown at $37^{\circ} \mathrm{C}$ for 24 hours. For each strain, $1 \mathrm{~mL}$ of active stock solution (approximately $10^{7} \mathrm{CFU} / \mathrm{mL}$ ) was transferred to $2 \mathrm{~mL}$ of Eppendorf tube. The cultures were then centrifuged at $10,000 \mathrm{rpm}$ for $10 \mathrm{~min}$. The pellets were retained and re-suspended with $1 \mathrm{~mL}$ of phosphate-buffered saline (PBS). For viable counts, each of the tubes containing re-suspended bacterial suspension (approximately $10^{7} \mathrm{CFU} / \mathrm{mL}$ ) of $S$. aureus KCTC-1621 and S. enterica ATCC-4731 was inoculated with $100 \mu \mathrm{L}$ oil at MIC concentration in $900 \mu \mathrm{L} \mathrm{NB}$ broth, and kept at $37^{\circ} \mathrm{C}$. Samples for viable cell counts were taken out at $0,40,80,120,160$ and $200 \mathrm{~min}$ time intervals. The viable plate counts were monitored as followed: after incubation, $100 \mu \mathrm{L}$ of the re-suspended culture was diluted into $900 \mu \mathrm{L}$ PBS, there by diluting it 10-fold. A $100 \mu \mathrm{L}$ sample of each treatment was diluted and spread on the surface of NB agar. The colonies were counted after 24 hours of incubation at $37^{\circ} \mathrm{C}$ (Bajpai et al. 2013). The controls were inoculated without oil for each bacterial strain with same experimental condition as mentioned above. Each assay in this experiment was replicated three times.

\section{Measurement of extracellular adenosine 5'-triphophate (ATP) concentration}

To determine the efficacy of L. lucidum flower oil on membrane integrity, the extracellular ATP concentrations were measured according to our previously described method (Bajpai et al., 2013). The working cultures of S. aureus KCTC-1621 and S. enterica ATCC4731 containing approximately $10^{7} \mathrm{CFU} / \mathrm{mL}$ inoculum were centrifuged for $10 \mathrm{~min}$ at $1,000 \mathrm{xg}$, and the supernatants were removed. The cell pellets were washed three times with $0.1 \mathrm{M}$ of sodium phosphate buffer $(\mathrm{pH}$ 7.0) and then cells were collected by centrifugation for $10 \mathrm{~min}$ at $1,000 \mathrm{xg}$. A cell suspension $\left(10^{7} \mathrm{CFU} / \mathrm{mL}\right)$ was prepared with $9 \mathrm{~mL}$ of sodium phosphate buffer $(0.1 \mathrm{M}$; $\mathrm{pH} 7.0$ ) and $0.5 \mathrm{~mL}$ of cell solution was taken into the Eppendorf tube for the treatment of L. lucidum flower oil. Then, the different concentrations (control and MIC) of L. lucidum flower oil were added to the cell solution. Samples were maintained at room temperature for 30 min, centrifuged for $5 \mathrm{~min}$ at 2,000 $\mathrm{xg}$, and incubated in ice immediately to prevent ATP loss until measurement. The extracellular (upper layer) ATP concentrations were measured using an ATP bioluminescent assay kit (Sigma, USA) which comprised ATP assay mix contain-ing luciferase, luciferin, $\mathrm{MgSO}_{4}$, dithiothreitol (DTT), ethylenediamine tetraacetic acid (EDTA), bovine serum albumin (BSA) and tricine buffer salts. The ATP concen-tration of the supernatants, which represented the extracellular concentration, was determined using a luminescence reader after the addition of $100 \mu \mathrm{L}$ of ATP assay mix to $100 \mu \mathrm{L}$ of supernatant. The emission and excitation wavelengths were 520 and $420 \mathrm{~nm}$, respectively.

\section{Assay of potassium ions efflux}

Our previously described method was used to determine the amount of the potassium ions (Bajpai et al., 2013). The concentration of free potassium ions in bacterial suspensions of $S$. aureus KCTC-1621 and S. enterica ATCC-4731 was measured after the exposure of bacterial cells to L. lucidum flower oil at MIC concentration in sterile peptone water for $0,30,60$ and 120 min. At each pre-established interval, the extra-cellular potassium concentration was measured by a photometric procedure using the calcium/potassium kit. Similarly control was also tested without adding $L$. lucidum flower oil. Results were expressed as amount of extracellular free potassium (mM) in the growth media in each interval of incubation.

\section{Measurement of release of 260-nm absorbing cellular materials}

The measurement of the release of 260-nm-absorbing materials from $S$. aureus KCTC-1621 and S. enterica ATCC-4731 cells was carried out in aliquots of $2 \mathrm{~mL}$ of the bacterial inocula in sterile peptone water $(0.1 \mathrm{~g} / 100$ $\mathrm{mL}$ ) added of L. lucidum flower oil MIC concentration at $37^{\circ} \mathrm{C}$. At 0,30 and $60 \mathrm{~min}$ time interval of treatment, cells were centrifuged at $3,500 \mathrm{xg}$, and the absorbance of the obtained supernatant was measured at $260 \mathrm{~nm}$ using a 96-well plate ELISA reader (Bajpai et al., 2013). Similarly control was also tested without adding $L$. lucidum flower oil. Results were expressed in terms of optical density of 260-nm absorbing materials in each interval with respect to the ultimate time.

\section{Measurement of cell membrane permeability}

Effect of L. lucidum flower oil on cell membrane permeability of test microorganism was determined as described previously (Patra et al., 2015) and expressed in terms of relative electrical conductivity. Prior to the assay, cultures of test microorganisms were incubated at $37^{\circ} \mathrm{C}$ for 10 hours, followed by centrifugation $(5,000$ $\mathrm{xg}$ ) for $10 \mathrm{~min}$, and washed with $5 \%$ glucose solution $(\mathrm{w} / \mathrm{v})$ until their electrical conductivities reached close to $5 \%$ glucose solution to induce an isotonic condition. Minimum inhibitory concentrations of L. lucidum flower oil acquired for both the test organisms were added to $5 \%$ glucose (isotonic solution), incubated at $37^{\circ} \mathrm{C}$ for 8 hours, and the electrical conductivities $\left(\mathrm{L}_{\mathrm{a}}\right)$ of the reaction mixtures were determined. Further, electrical conductivities of the bacterial solutions were measured at 2 hours of intervals for a total duration of 8 hours $\left(\mathrm{L}_{\mathrm{b}}\right)$. The electrical conductivity of each test pathogen in isotonic solution killed by boiling water for $5 \mathrm{~min}$ served as a control $\left(\mathrm{L}_{\mathrm{c}}\right)$. The relative electrical conductivity was measured using an electrical conductivity meter. The permeability of bacteria membrane was calculated according to the following formula:

Relative conductivity $(\%)=\mathrm{L}_{\mathrm{a}}-\mathrm{L}_{\mathrm{b}} / \mathrm{L}_{\mathrm{c}} \times 100$ 


\section{Statistical analysis}

All data are expressed as the mean \pm SD by measuring three independent replicates. Analysis of variance using one-way ANOVA followed by Duncan's multiple test to test the significance of differences at the level of $0<0.05$ using a SAS software.

\section{Results}

\section{Chemical composition of L. lucidum flower oil}

The GC-MS analysis of the L. lucidum flower oil led to the identification of 44 different components representting $85.2 \%$ of the total oil. The hydrodistillation of $L$. lucidum flower yielded light yellowish oil with the major composition of the oil containing oxygenated mono- and sesquiterpenes and their aromatic hydrocarbons along with some other essential phytochemicals. As shown in Table I, the major components of L. lucidum flower essential oil were identified to be styrene glycol $(26.6 \%)$, formic acid $(14.6 \%)$, capsaicin (2.9\%), 4-propoxy-2,5-dimethoxy amphetamine (2.8\%), falcarinol (2.8\%), 3,4-epoxyguai-1(10)-en-6,12-olide (2.6\%), 7-O-methyl-3-desoxy-norreticuline (2.5\%), 2,3dihydrobenzofuran $(2.3 \%)$, homofascaplysin C $(2.2 \%)$,

\section{Table I}

\section{GC-MS chemical composition of essential oil isolated from the floral parts of L. lucidum by hydrodistillation}

\begin{tabular}{|c|c|c|c|c|}
\hline No. & $\mathrm{RTa}$ & Compound $b$ & Composition $(\%)^{c}$ & Identification $^{\mathrm{d}}$ \\
\hline 1. & 1.52 & Formic acid & 14.58 & EI-MS \\
\hline 2. & 5.31 & 1-N-Methyluracil & 0.66 & EI-MS \\
\hline 3. & 6.10 & 2-Phenylimidazoline & 0.67 & EI-MS \\
\hline 4. & 6.18 & 2-Ethylmalonimide & 0.44 & EI-MS \\
\hline 5. & 6.38 & 5-Ethyl-1H-indene & 0.95 & EI-MS \\
\hline 6. & 7.48 & 2,3-Dihydrobenzofuran & 2.30 & EI-MS \\
\hline 7. & 7.56 & 4-Mercaptophenol & 0.73 & EI-MS \\
\hline 8. & 8.73 & Acetovanillone & 0.75 & EI-MS \\
\hline 9. & 8.86 & Durenol & 0.84 & EI-MS \\
\hline 10. & 9.56 & 8-Azaisochroman-1, 4-dione & 0.39 & EI-MS \\
\hline 11. & 9.96 & Tryptophol acetate & 0.69 & EI-MS \\
\hline 12. & 10.39 & Styrene glycol & 26.63 & EI-MS \\
\hline 13. & 10.83 & Falcarinol (Z) & 2.77 & EI-MS \\
\hline 14. & 10.96 & 1,2,3,4-Tetrahydro-7-chlorobenz [c] acridine & 0.53 & EI-MS \\
\hline 15. & 11.19 & Fucitol-1-D-2, 3, 4-trimethyl-1, 5-diacetate & 0.61 & EI-MS \\
\hline 16. & 11.72 & Ethyl homovanillate & 0.56 & EI-MS \\
\hline 17. & 11.87 & 5-Propyl guaiacol & 0.91 & EI-MS \\
\hline 18. & 12.06 & Cassie ketone & 0.88 & EI-MS \\
\hline 19. & 12.46 & Caproic acid & 0.68 & EI-MS \\
\hline 20. & 12.79 & 3, 4-Mpoxyguai-1 (10) - en-6, 12-olide & 2.63 & EI-MS \\
\hline 21. & 12.87 & Megastigmatrienone 2 & 0.84 & EI-MS \\
\hline 22 & 13.14 & Ethyltributylstannane & 0.88 & EI-MS \\
\hline 23 & 13.21 & 2-Dinitrophenyl sulphone & 1.39 & EI-MS \\
\hline 24 & 13.42 & Homofascaplysin C & 2.24 & EI-MS \\
\hline 25 & 13.51 & Elymoclavine & 1.81 & EI-MS \\
\hline 26 & 14.11 & Capsaicin & 2.86 & EI-MS \\
\hline 27 & 14.27 & Isopropyl myristate & 0.58 & EI-MS \\
\hline 28 & 14.62 & Uvidin B & 1.72 & EI-MS \\
\hline 29 & 15.07 & 7-O-methyl-3-desoxy-norreticuline & 2.46 & EI-MS \\
\hline 30. & 15.32 & 1-Methylinosine & 0.72 & EI-MS \\
\hline 31. & 15.97 & Methyl palmitate & 0.66 & EI-MS \\
\hline 32. & 16.00 & Weberine & 0.62 & EI-MS \\
\hline
\end{tabular}


Table I

GC-MS chemical composition of essential oil isolated from the floral parts of L. lucidum (Cont.)

\begin{tabular}{|lllcc|}
\hline No. & RTa & Compound & Composition $(\%)^{\mathrm{c}}$ & Identification $^{\mathrm{d}}$ \\
\hline 33. & 16.34 & Palmitic acid & 0.72 & EI-MS \\
34. & 16.37 & Butyl-phthalate & 0.62 & EI-MS \\
35. & 16.49 & (+, -) Isogatholactone & 0.74 & EI-MS \\
36. & 16.70 & 4-Propoxy-2, 5-dimethoxy amphetamine & 2.78 & EI-MS \\
37. & 16.92 & 12-Octadecenal & 0.54 & EI-MS \\
38. & 17.02 & Norpluvine & 0.75 & EI-MS \\
39. & 17.42 & 18-Crown-6-ether & 0.83 & EI-MS \\
40. & 17.65 & 10, 13-Octadecadienoic acid methyl ester & 0.36 & EI-MS \\
41. & 17.72 & Methyl oleate & 0.52 & EI-MS \\
42. & 17.89 & n-Eicosanol & 0.70 & EI-MS \\
43. & 22.43 & 6-Chloro-3-methyl-4-phenylcinnoline & 0.88 & EI-MS \\
44. & 26.21 & Aspidofractinine-3-methanol & 1.51 & EI-MS \\
\hline
\end{tabular}

aRetention time (RT); bCompounds listed in order of elution from a DB-5 capillary column; cPercentage based on FID peak area normalization; dIdentification based on computer matching of electron ionization-mass spectra (EI-MS) using Wiley and NIST libraries for the GC-MS system

elymoclavine $(1.8 \%)$, uvidin B (1.7\%), aspidofractinine-3 -methanol (1.5\%) and 2-dinitrophenyl sulphone (1.4\%). The essential oil composition of L. lucidum flower has not been reported before and therefore, our results can be considered as the first report on the essential oil composition of L. lucidum.

\section{Antibacterial activity}

The antibacterial activity of L. lucidum flower oil against the tested food-borne pathogenic bacteria was qualitatively and quantitatively determined by the presence or absence of inhibition zones. As presented in Table II, the oil $(1 \mathrm{mg} /$ disc $)$ exhibited potent inhibitory effect against the tested food-borne pathogenic bacteria. In this assay, Gram-positive bacteria such as $S$. aureus KCTC-1621, B. subtilis KCTC-3569 and L. monocytogenes KCTC-3569 were found to be the most inhibited bacterial pathogens by L. lucidum flower oil with their respective diameters of inhibition zones of $19.7 \pm 0.3$, $18.3 \pm 0.2$ and $17.2 \pm 0.2 \mathrm{~mm}$, whereas Gram-negative bacteria including S. enterica ATCC-4731 and E. coli O157:H7 were inhibited moderately with diameters of inhibition zones of $15.2 \pm 0.2$ and $14.6 \pm 0.2 \mathrm{~mm}$, respectively (Table II). In this assay, L. lucidum flower oil exhibited significant $(p<0.05)$ antibacterial effect when compared with standard drug tetracycline at the used concentration. The diameters of inhibition zones of L. lucidum flower oil against Gram-positive bacteria were found to be higher than Gram-negative bacteria (Table II). The DMSO, as a negative control had no inhibitory effect at the used concentration.

\section{Minimum inhibitory and bactericidal concentrations}

L. lucidum flower oil showed potent inhibitory effect as

Table II

Antibacterial potential essential oil of isolated from the floral parts of L. lucidum against pathogenic bacteria

Pathogens

Pathogens

Staphylococcus aureus KCTC-1621

Bacillus subtilis KCTC-3569

Listeria monocytogenes KCTC-3569

Salmonella enterica ATCC-4731

Escherichia coli $\mathrm{O} 157: \mathrm{H7}$
aEssential oil from the floral parts of Ligustrum lucidum

bDiameters of inhibition zones (mm)

Essential oil

Tetracyclinc

$19.66 \pm 0.33$

$24.22 \pm 0.05$

$18.33 \pm 0.24$

$26.27 \pm 0.07$

$17.23 \pm 0.22$

$15.21 \pm 0.21$

$27.10 \pm 0.02$

$14.62 \pm 0.17$
Susceptibility

\begin{tabular}{r|r|}
\hline MICd & MBCe \\
250 & 250 \\
250 & 500 \\
500 & 500 \\
1,000 & 1,000 \\
1,000 & 2,000 \\
\hline
\end{tabular}

${ }^{a}$ L. lucidum flower essential oil; bDiameters of inhibition zones of L. lucidum flower essential oil (Tested volume $20 \mu \mathrm{L}$, corresponding to $1 \mathrm{mg} / \mathrm{disc}$ ); cStandard $(25 \mu \mathrm{g} / \mathrm{disc}$ ); dMinimum inhibitory concentration (values in $\mu \mathrm{g} / \mathrm{mL}$ ); eMinimum bactericidal concentration (values in $\mu \mathrm{g} / \mathrm{mL}$ ). All values were expressed as mean $\pm \mathrm{SD}$ of three parallel measurements $(n=3)$ 
MIC and MBC values against all the tested food-borne pathogenic bacteria. As shown in Table II, the MIC and MBC values of L. lucidum flower oil against the tested Gram-positive bacteria of $S$. aureus KCTC-1621, B. subtilis KCTC-3569 and L. monocytogenes KCTC-3569 were found in the range of 250 to $500 \mu \mathrm{g} / \mathrm{mL}$, while for Gram-negative bacteria such as S. enterica ATCC-4731 and E. coli O157:H7, the MIC and MBC values were found in the range of $(1 \mathrm{mg} / \mathrm{mL}$ for each bacterial pathogen) and (1-2 mg/mL), respectively. In this assay, S.aureus KCTC-1621, B. subtilis KCTC-3569 and L. monocytogenes KCTC-3569 were found extremely susceptible pathogens to L. lucidum oil with MIC and MBC values of (250, 250 and $500 \mu \mathrm{g} / \mathrm{mL})$ and (250, 500 and $500 \mu \mathrm{g} / \mathrm{mL}$ ), respectively. However, in this study, both Gram-positive and Gram-negative bacteria were found susceptible to L. lucidum flower oil (Table II).

\section{Effect on cell viability}

Based on the sensitivity of the test food-borne pathogens, one Gram-positive (S. aureus KCTC-1621) and a Gram-negative (S. enterica ATCC-4731) bacteria were selected as the model organisms for further studies to confirm the antibacterial mode of action of L. lucidum flower essential oil. In this regard, further study was carried out to evaluate the effect of L. lucidum oil on the viable counts of the selected bacteria such as S. aureus KCTC-1621 and S. enteric ATCC-4731. The effect of $L$. lucidum oil on the growth of tested bacterial pathogens demonstrated reduced viability at the used concentra-

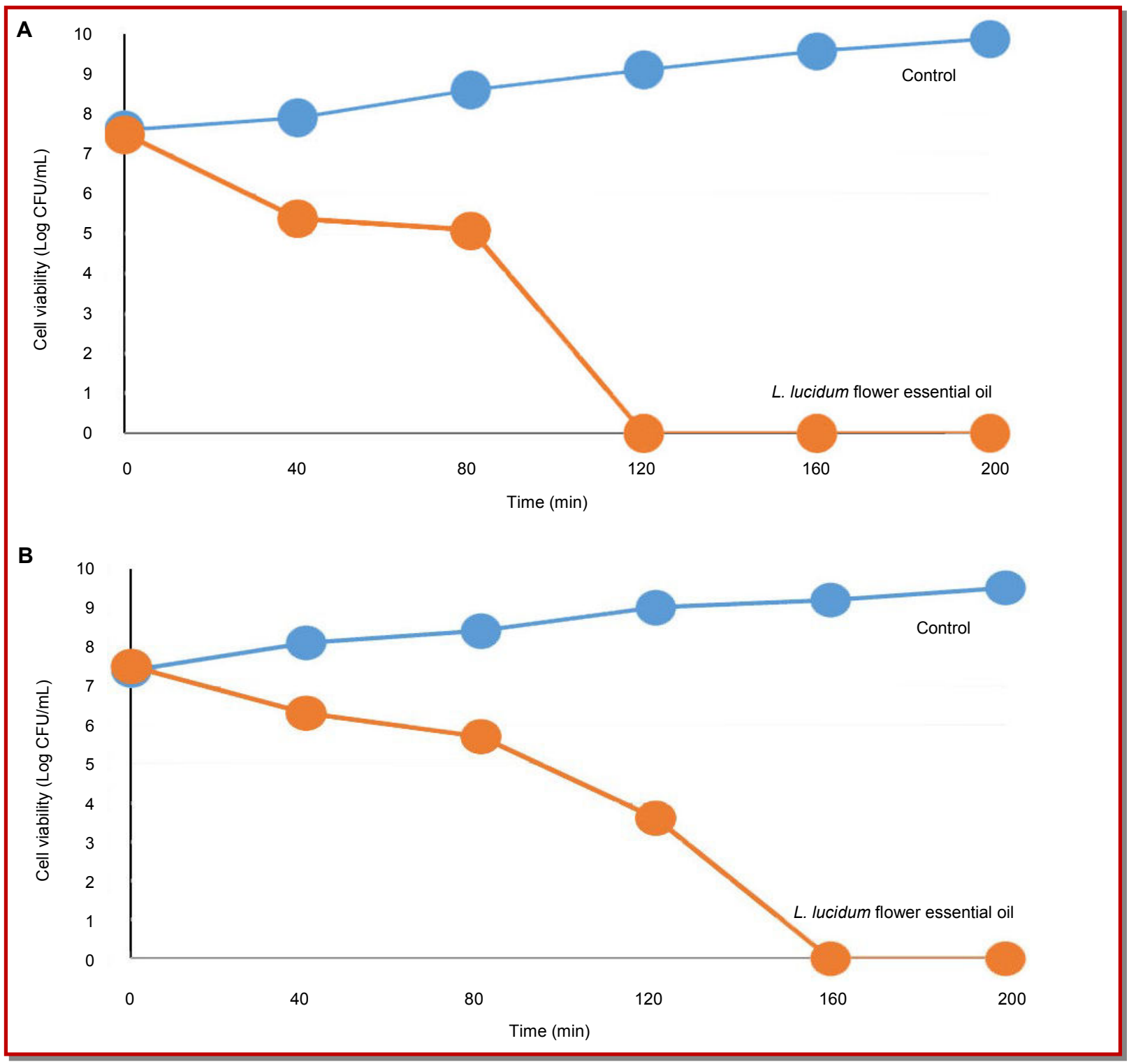

Figure 1: Effect of flower essential oil of Ligustrum lucidum on the viability of the tested pathogenic bacteria of S. aureus KCTC1621 (A) and S. enterica ATCC-4731 (B). CT: control without treatment. Data are expressed as mean \pm SD $(n=3)$ 
tion (Figure 1). Exposure of 0 to $80 \mathrm{~min}$ of L. lucidum flower oil did not cause severe decline on the inhibition of cell viability of the tested pathogens, however, considerable amount of inhibitory effect was observed on the inhibition of the cell viability of the tested bacteria of S. aureus KCTC-1621 and S. enterica ATCC4731 at the exposure time of 120 and $160 \mathrm{~min}$, respectively. Interestingly, the exposure of L. lucidum oil for $120 \mathrm{~min}$ revealed complete inhibition of colony forming unit (CFU) numbers against $S$. aureus KCTC1621 (Figure 1a). On the other hand, complete inhibition of cell viable counts of $S$. enterica ATCC-4731 was observed at $160 \mathrm{~min}$ exposure time of L. lucidum oil, and no CFU formation was observed (Figure 1b).

\section{Measurement of ATP}

The effect of L. lucidum seed oil on the determination of extracellular ATP concentrations in S. aureus KCTC1621 and S. enterica ATCC-4731 cells is presented in Figure 2. The extracellular ATP concentrations in the control cells S. aureus KCTC-1621 and S. enterica ATCC4731 were found to be 0.8 and $0.4 \mathrm{pg} / \mathrm{mL}$, respectively (Figure 2). S. aureus KCTC-1621 and S. enterica ATCC4731 cells treated with L. lucidum flower oil at MIC concentration showed significant $(\mathrm{p}<0.05)$ increase in the release of extracellular ATP concentration. In this assay, the extracellular ATP concentrations for S. aureus KCTC-1621 and $S$. enterica ATCC-4731 cells were measured to be 2.5 (Figure 2a) and 2.2 (Figure 2b) pg/ $\mathrm{mL}$, respectively.

\section{Measurement of potassium ion leakage}

In this assay, antibacterial mode of action of L. lucidum flower oil was confirmed by the release of potassium ions from the treated cells of S. aureus KCTC-1621 and S. enteric ATCC-4731 (Figure 3). The release of potassium ions from the bacterial cells occurred imme- diately after the addition of L. lucidum flower oil at MIC concentration following a sturdy loss along the specified time period (Figure 2). However, no leakage of potassium ion was observed in control cells of $S$. aureus KCTC-1621 and S. enterica ATCC-4731 during the study (Figure 3).

\section{Measurement of $260 \mathrm{~nm}$ materials}

Further, antibacterial mode of action of L. lucidum flower oil was visualized by the confirmation on the leakage of $260 \mathrm{~nm}$ absorbing materials when the test food-borne pathogens exposed to L. lucidum flower oil at MIC. In this assay, exposure of S. aureus KCTC-1621 and S. enterica ATCC-4731 to L. lucidum flower oil caused rapid loss of $260-\mathrm{nm}$ absorbing materials from the bacterial cells. The optical density $(260 \mathrm{~nm})$ of the culture filtrates of S. aureus KCTC-1621 and S. enterica ATCC-4731 cells exposed to L. lucidum flower oil revealed an increasing release of $260 \mathrm{~nm}$ absorbing materials with respect to exposure time (Figure 4). However, no changes in the optical density of control cells of test pathogens were observed during the study. After $60 \mathrm{~min}$ of treatment, approximately more than 2fold increase was observed in the optical density of the bacterial cell culture filtrates treated with L. lucidum flower oil (Figure 4).

\section{Measurement of cell membrane permeability}

Figure 5 demonstrates the effect of MIC exposure of $L$. lucidum flower oil on the membrane permeability of $S$. aureus KCTC-1621 and S. enterica ATCC-4731 in terms of their relative electrical conductivities. L. lucidum flower oil exhibited time-dependent effect in this assay, and the relative electrical conductivity of each test pathogen was increased timely. However, flower oil exerted significantly $(\mathrm{p}<0.05)$ higher effect on $S$. aureus KCTC-1621 (Figure 5a) with increased proportion of

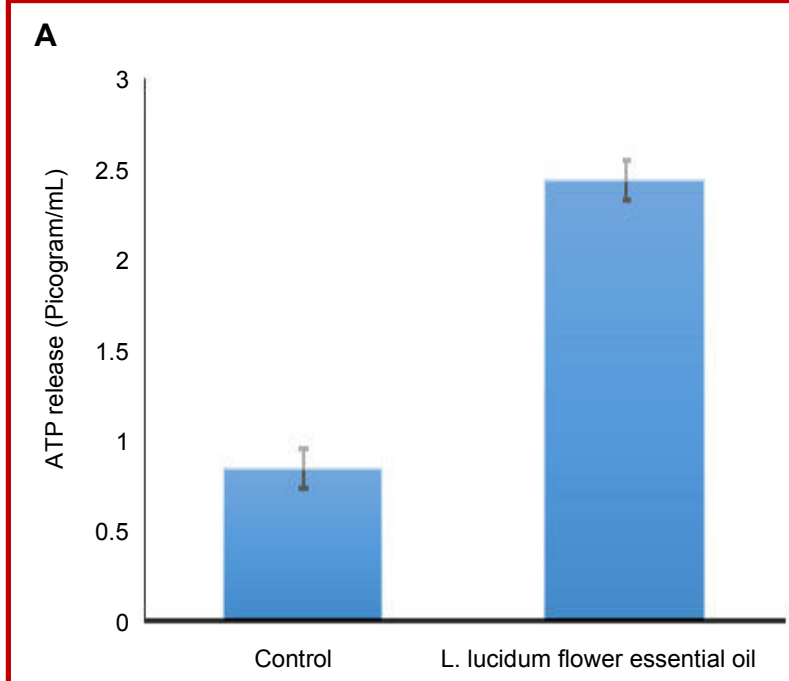

B

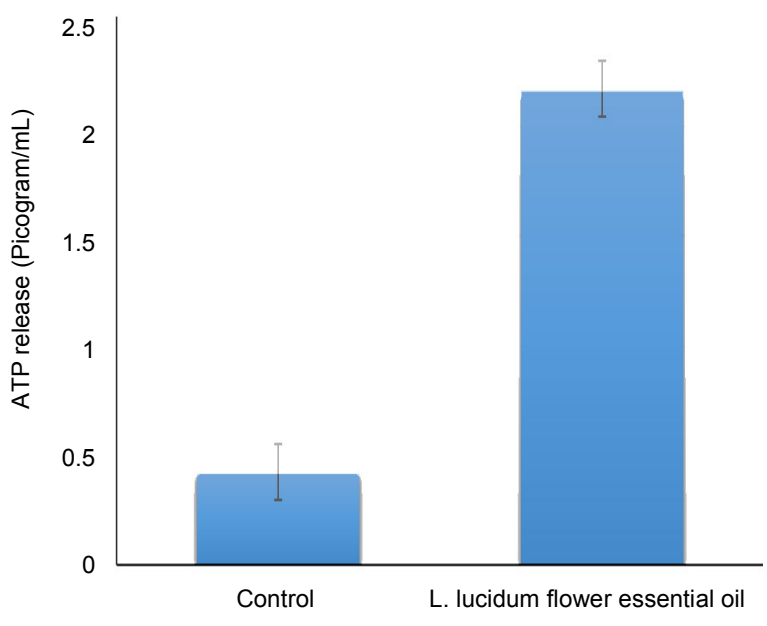

Figure 2: Effect of flower essential oil of Ligustrum lucidum on extracellular ATP concentration of S. aureus KCTC-1621 (A) and S. enterica ATCC-4731 (B). Data are expressed as mean \pm SD $(n=3)$ 


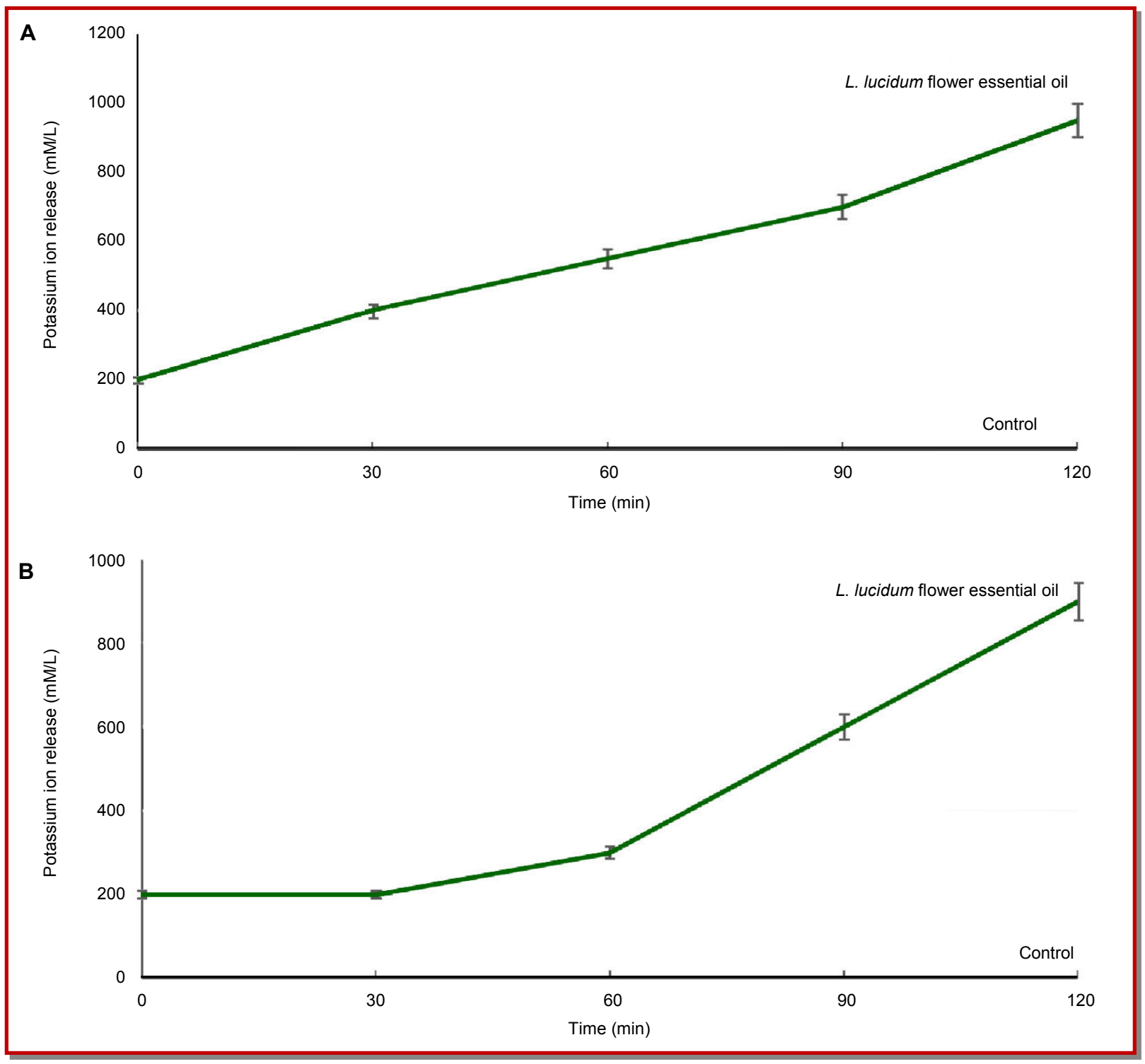

Figure 3: Effect of flower essential oil of Ligustrum lucidumon leakage of potassium ions from the tested pathogenic bacteria of $S$. aureus KCTC-1621 (A) and S. enterica ATCC-4731 (B). CT: control without treatment

relative electrical conductivity as compared to $S$. enterica (Figure 5b). No relative electrical conductivity was observed in untreated samples as a control.

\section{Discussion}

The results of the antibacterial screening showed that $L$. lucidum flower oil had strong and consistent inhibitory effect against the tested food-borne pathogens as confirmed by the inhibitory effect of L. lucidum flower oil showing different susceptibility rate against the tested food-borne pathogens.

Essential oils are volatile and odorous principles of plant secondary metabolism which have wide applications in food flavoring and preservation Indus- tries (Bajpai et al., 2012). In recent years, several researchers have reported that mono-terpene or sesquiterpene hydrocarbons and their oxygenated derivatives, which are major components of essential oils, exhibit potential antimicrobial activity (Cakir et al., 2004). These findings strongly support the outcomes of this study as L. lucidum flower oil was also found to contain oxygenated sesquiterpenes and their respective hydrocarbons, confirming its efficacy as natural antimicrobial agent.

Furthermore, the results from viable count assay revealed that exposure of L. lucidum flower oil had a rigorous effect on the cell viability of the tested bacterial pathogens. L. lucidum flower oil exerted its maximum bactericidal activity as evident by the significant reduction in microbial counts and complete inhibition 


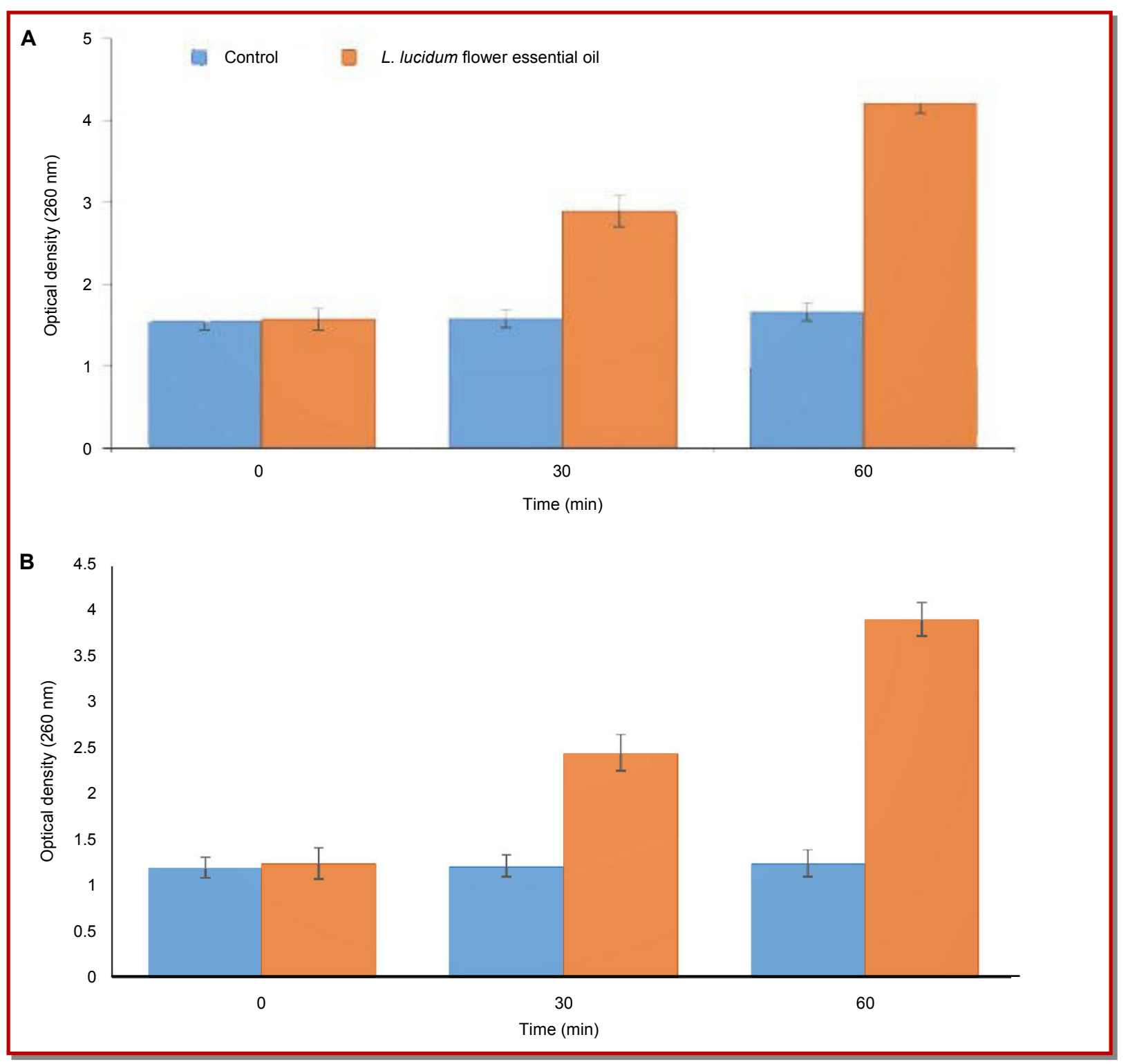

Figure 4: Effect of flower essential oil of Ligustrum lucidum on the release rate of $260 \mathrm{~nm}$ absorbing material from S. aureus KCTC1621 (A) and S. enterica ATCC-4731 (B). Data are expressed as mean \pm SD ( $\mathrm{n}=3)$

of S. aureus KCTC-1621 and S. enterica ATCC-4731 cell viable counts at the exposure time of 120 and $160 \mathrm{~min}$, respectively. Previously we confirmed the inhibitory effects of various plant-based essential oils on the cell viability of food-borne pathogenic bacteria (Bajpai et al., 2012; Bajpai et al., 2013; Bajpai et al., 2015). Similar to our findings, other essential oils also exerted inhibitory effects against various food-borne pathogens (Al-Reza et al., 2010).

Further, in this study, membrane permeability parameters such as determination of extracellular ATP concentration, leakage of potassium ions, loss of $260 \mathrm{~nm}$ absorbing materials, and measurement of relative electrical conductivity were used to determine the mode of action of L. lucidum flower oil against selected food-borne pathogenic bacteria. It was confirmed that L. lucidum flower oil had detrimental effect on damaging cell membrane integrity, resulting in the increased extracellular ATP concentration from the treated cells. The use of ATP has been confirmed in various cell functions including transport work moving substances across cell membranes which might be an important parameter to understand the mode of action of antibacterial agents.

The results of our study on the determination of extracellular ATP concentration showed an increasing rate of extracellular ATP concentrations after $S$. aureus KCTC-1621 and S. enteric ATCC-4731 cells exposed to L. lucidum flower oil. This phenomenon may lead to significant impairment in membrane permeability of 


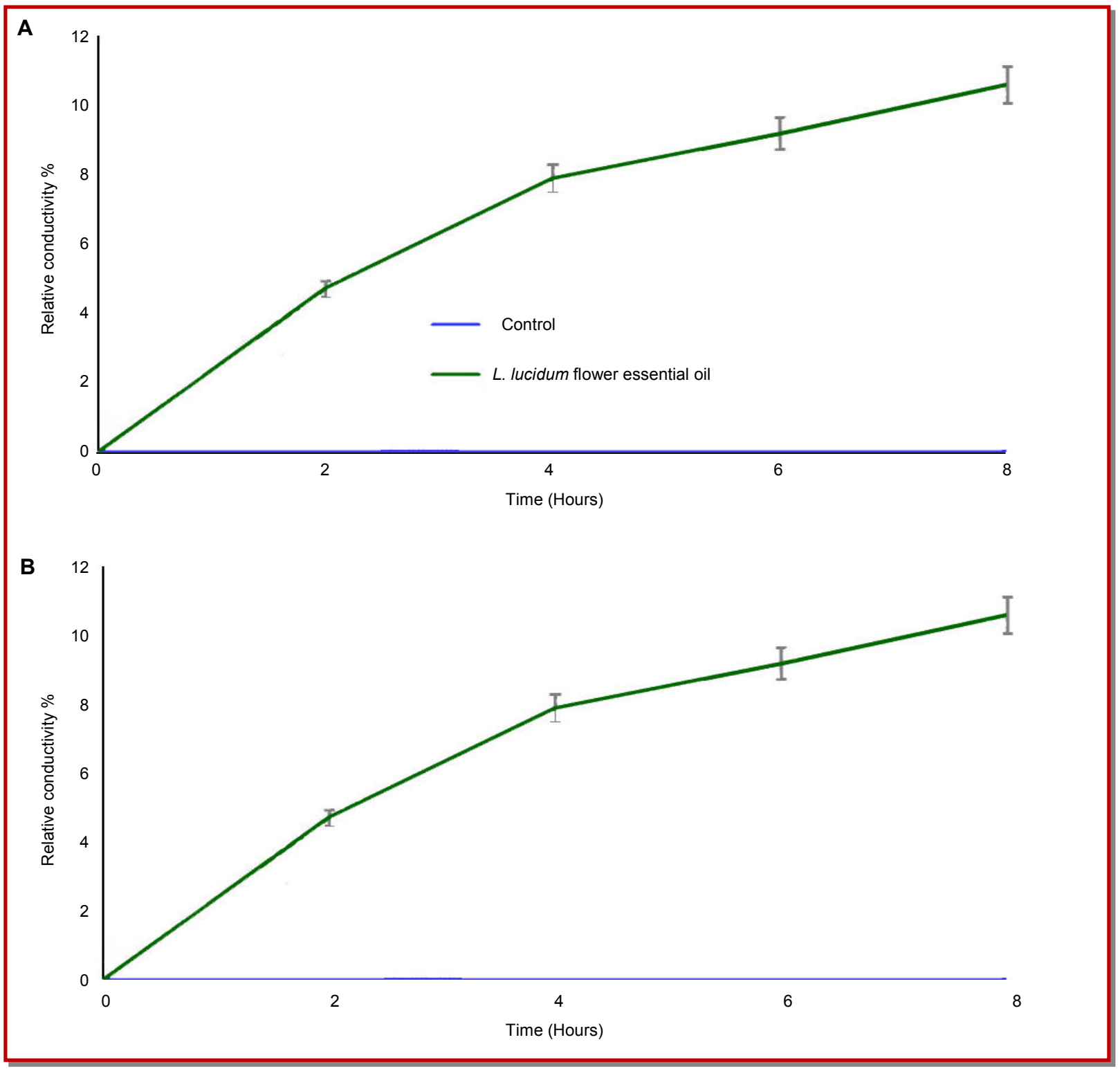

Figure 5: Effect offlower essential oil of Ligustrum lucidum on membrane permeability of S. aureus KCTC-1621 (A) and S. enterica ATCC -4731 (B). Data are expressed as mean \pm SD $(n=3)$

the tested bacteria by L. lucidum flower oil, which caused the intracellular ATP leakage through defective cell membrane as also reported previously (Bajpai et al., 2013). It has been found that cells of B. subtilis treated with essential oil components resulted in the release of increased level of extracellular ATP pool (Helander et al., 1998). Subsequently, the antibacterial effect might be established because of proton motive force inhibition, mitochondrial respiratory inhibition, inhibition of substrate oxidation and active transportation, and loss of pool metabolites, as well as disruption of synthesis of macromolecules, proteins, lipids and polysaccharides may also occur. In general, leakage of intracellular material is induced by many antimicrobial agents resulting in the death of a cell (Denyer, 1990; Farag et al., 1989).
Moreover, in this study, L. lucidum flower oil exerted remarkable efficacy on the release of potassium ions from the treated cells of S. aureus KCTC-1621 and S. enterica ATCC-4731 cells at MIC concentration. The bacterial plasma membrane provides a permeability barrier to the passage of small ions such as potassium ions which are necessary electrolytes, facilitating cell membrane functions and maintaining proper enzyme activity. This impermeability to small ions is regulated by the structural and chemical composition of the membrane itself. Increases in the leakage of potassium ions could be an indication of disruption of this permeability barrier.

Maintaining ion homeostasis is integral to the maintenance of the energy status of the cell including solute 
transportation, regulation of metabolism, control of turgor pressure and motility (Cox et al., 2001). Therefore, even relatively slight changes to the structural integrity of cell membranes can severely affect cell metabolism and lead to cell death, and potassium ion efflux (Cox et al., 2001).

Measurement of specific cell leakage markers such as $260 \mathrm{~nm}$ absorbing materials is an indication of membrane sensitivity to specific antimicrobial agent in relationship to control cells. In this study, L. lucidum flower oil exhibited significant potential on the release of $260 \mathrm{~nm}$ materials (DNA and RNA) from the cells of tested bacteria when exposed to MIC concentration. This directly indicates the confirmation of leakage of $260 \mathrm{~nm}$ absorbing materials from the bacterial cells treated with L. lucidum flower oil. The observation that the amount of loss of $260 \mathrm{~nm}$ absorbing materials was as extensive as the leakage of potassium ions might indicate that the membrane structural damage sustained by the bacterial cells resulted in release of macromolecular cytosolic constituents (Farag et al., 1989). The effect of carvacrol, an essential oil component, on bacterial proton motive force was strongly correlated to the leakage of various substances, such as ions, ATP, nucleic acids and amino acids (Herranz et al., 2001). This suggested that monitoring $\mathrm{K}^{+}$efflux and release of $260 \mathrm{~nm}$ absorbing materials from $S$. aureus KCTC-1621 and S. enterica ATCC-4731 might be more sensitive indicators of membrane damage and loss of membrane integrity (Cox et al., 2001).

Furthermore, this study revealed that L. lucidum flower oil has ability to disrupt the plasma membrane as confirmed by the changes observed in the relative electrical conductivity of both the tested bacteria. Similarly oil from different plant origin has also shown the remarkable effect on relative electrical conductivity parameters of food-borne pathogens (Patra et al., 2015). Maintaining membrane permeable integrity is essential for overall metabolism of a bacterial cell, hence, changes in the relative electrical conductivity on membrane integrity may severely hamper the cell metabolism, which may eventually lead cell death (Cox et al., 2001). Based on the findings of this study, we hypothesized an antibacterial mechanism of action of L. lucidum flower oil that accumulation of the oil in the plasma membrane caused instant loss of the cell integrity and became increasingly more permeable to ions and other essential metabolites that might be the reason for the establishment of the antibacterial activity of L. lucidum flower oil. Excessive leakage of cytoplasmic material is used as indication of gross and irretrievable damage to the plasma membrane (Cox et al., 1998).

Moreover, some essential oils exert greater inhibitory effect against broad-range of pathogenic microorganisms. However, in this study, the Gram-positive bacteria were found to be more susceptible to the $L$. lucidum flower oil than Gram-negative bacteria. The hydrophilic cell wall structure of Gram-negative bacteria is constituted essentially of lipo-polysaccharide that blocks the penetration of hydrophobic components and avoids the accumulation of essential oils in target cell membrane (Bezic et al., 2003). The single membrane of Gram-positive bacteria is considerably more accessible to permeation by hydrophilic components of essential oil in the target sites. This might be the reason that Gram-positive bacteria were found to be more sensitive to the L. lucidum flower oil than those of Gram-negative bacteria. Similar findings on the susceptibility of various essential oils against food-borne pathogenic bacteria including Gram-positive and Gram-negative bacteria have been reported previously (Bajpai et al., 2012; Bajpai et al., 2013).

The results of this study indicate that the L. lucidum flower essential oil is able to disrupt membrane functions of both Gram-positive and Gram-negative bacteria. Hence, we conclude that L. lucidum flower oil exerts its inhibitory effect through permeabilization of the cell membrane associated with generalized membrane-disrupting effects, and this corresponds to a simultaneous reduction in the number of viable bacteria, loss of $260 \mathrm{~nm}$ absorbing materials, and leakage of potassium ions with decreased pool of extracellular ATP and increase in relative electrical conductivity being indicative of loss of membrane integrity.

\section{Conclusion}

L. lucidum flower oil showing significant antibacterial activity, can be used as a natural antimicrobial agent in food and pharmaceutical industries to combat against food-borne pathogens.

\section{References}

Aiyelaagbe OO, Adesoganm K, Ekundayo O, Gloer JB. Antibacterial diterpenoids from Jatropha podagrica Hook. Phytochemistry 2007; 68: 2420-25.

Al-Reza SM, Rahman A, Lee JH, Kang SC. Potential roles of essential oil and organic extracts of Zizyphus jujube in inhibiting food-borne pathogens. Food Chem. 2010; 119: 98186.

Bajpai VK, Sharma A, Baek KH. Antibacterial mode of action of Ginkgo biloba leaf essential oil: Effect on morphology and membrane permeability. Bangladesh J Pharmacol. 2015; 10: 337-50.

Bajpai VK, Sharma A, Baek KH. Antibacterial mode of action of Cudrania tricuspidata fruit essential oil, affecting membrane permeability and surface characteristics of food-borne pathogens. Food Cont. 2013; 32: 582-90.

Bajpai VK, Baek KH, Kang SC. Control of Salmonella in foods by using essential oils: A review. Food Res Int. 2012; 45: 722- 
34.

Bezic N, Skocibusic M, Dinkic V, Radonic A. Composition and antimicrobial activity of Achillea clavennae L. essential oil. Phytother Res. 2003; 17: 1037-40.

Cakir A, Kordali S, Zengin H, Izumi S, Hirata T. Composition and antifungal activity of essential oils isolated from Hypericum hyssopifolium and Hypericum heterophyllum. Flav Frag J. 2004; 19: 62-68.

Chen J. Chinese medical herbology and pharmacology. City of Industry, CA, Art of Medicine Press, Inc., 2012, pp 962-63.

Cox SD, Gustafson JE, Mann CM, Markhan JL, Liew YC, Hartlnd RP. Tea tree oil causes $\mathrm{Kp}$ leakage and inhibits respiration in Escherichia coli. Lett Appl Microbiol. 1998; 26: 355-58.

Cox SD, Mann CM, Markhan JL, Gustafson JE, Warmington JR, Wyllie SG. Determining the antimicrobial action of tea tree oil. Molecules 2001; 6: 87-91.

da Silveira SM, Cunha A. Jr., Scheuermann GN, Secchi FL, Vieira CRW. Chemical composition and antimicrobial activity of essential oils from selected herbs cultivated in the South of Brazil against food spoilage and food-borne pathogens. Ciencia Rural Santa Maria. 2012; 42: 1300-06.

Denyer SP. Mechanisms of action of biocides. Int Biodeter. 1990; 26: 89-100.

Farag RS, Daw ZY, Hewedi FM, El-Baroty GSA. Antimicrobial activity of some Egyptian spice essential oil. J Food Prot.
1989; 52: 665-67.

Helander IM, Alakomi HL, Latva-Kala K, Mattila-Sandholm T, Pol I, Smid EJ. Characterization of the action of selected essential oil components on Gram-negative bacteria. J Agric Food Chem. 1998; 46: 3590-95.

Herranz C, Chen Y, Chung HJ, Cintas LM, Hernandez PE, Montville TJ, Chikindas ML. Enterocin P selectively dissipates the membrane potential of Enterococcus faecium T136. Appl Environ Microbiol. 2001; 67: 1689-92.

Oussalah M, Cailet S, Soucier L, Lacroix M. Inhibitory effect of selected plant essential oils on the growth of four pathogenic bacteria: E. coli O157:H7, Salmonella typhimurium, Staphylococcus aureus and Listeria monocytogenes. Food Control. 2007; 18: 414-20.

Patra JK, Hwang H, Choi JW, Baek KH. Bacterial mechanism of bio-oil obtained from fast pyrolysis of Pinus densiflora against two food-borne pathogens, Bacillus cereus and Listeria monocytogenes. Food-borne Pathogens Dis. 2015; 12: 529-35.

Runyoro D, Ngassapa O, Vagionas K, Aligiannis N, Graikou K, Chinou I. Chemical composition and antimicrobial activity of the essential oils of four Ocimum species growing in Tanzania. Food Chem. 2010; 119: 311-16.

Yoon JI, Bajpai VK, Kang SC. Synergistic effect of nisin and cone essential oil of Metasequoia glyptostroboides Miki ex $\mathrm{Hu}$ against Listeria monocytogenes in milk samples. Food Chem Toxicol. 2011; 49: 109-14. 


\section{Your feedback about this paper}

1. Number of times you have read this paper 0

2. Quality of paper Click

3. Your comments

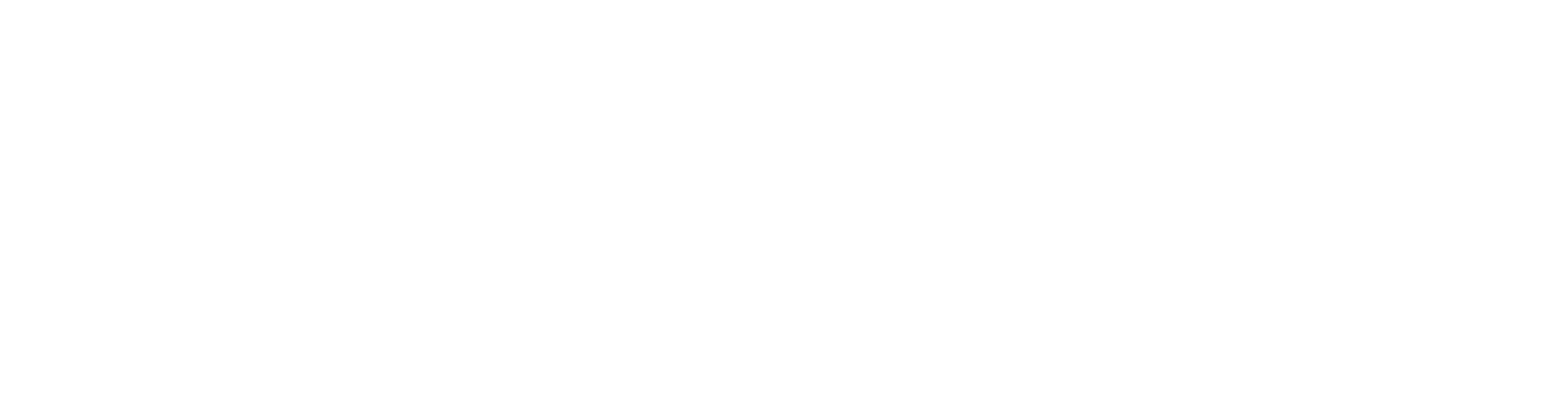

